\title{
THE INFLATIONARY IMPACT OF WAGE INDEXATION
}

\author{
FRANK HEINEMANN
}

CESIFo WORKING PAPER NO. 867

CAtegory 6: Monetary Policy AND InTERnAtional Finance

FEBRUARY 2003

\footnotetext{
An electronic version of the paper may be downloaded

- from the SSRN website: www.SSRN.com

- from the CESifo website: www.CESifo.de
} 


\title{
THE INFLATIONARY IMPACT OF WAGE INDEXATION
}

\begin{abstract}
It is an open question whether and how indexed wage contracts reduce welfare or raise average inflation. This paper analyzes the impact of indexed wage contracts on inflation and social welfare in a Barro-Gordon model with discretionary monetary policy by endogenizing social costs of indexation. Main results are: Wage indexation reduces the inflation bias but may raise the variance of inflation rates. In social optimum wages are fully indexed to the price level, but this requires optimal wage adjustments to productivity shocks. If wage adjustments to productivity are suboptimal, the second best solution calls for non-indexed wage contracts and a central banker with balanced aspiration levels of employment and real wages. In case of decentralized wage bargaining, a prohibition of wage indexation may improve welfare.
\end{abstract}

JEL Code: E24, E52.

Keywords: monetary policy, Phillips curve, wage bargaining, wage indexation.

Frank Heinemann

University of Munich

Dept of Economics

Ludwigstr. $28 R G$

80539 Muenchen

Germany

frank.heinemann@lrz.uni-muenchen.de 


\section{Introduction}

It has often been said that indexed contracts advance inflation. On one hand, wage indexation increases the slope of the Phillips curve and makes it more difficult to use monetary policy for stabilizing employment. Indexed bonds prevent that inflation depreciates the real value of government debt and indexed tax schemes decouple real revenues of a progressive income tax from inflation. Thereby, indexation reduces the government's gains from inflation and its incentive for expansionary monetary policy. On the other hand, indexation reduces social costs of inflation and the central bank's resistance to inflationary policy. These two effects influence the inflation bias in opposite directions, and within the standard model of monetary policy by Barro and Gordon (1983) it is not clear under which circumstances one or the other effect dominates (Mourmouras, 1993).

Wage indexation reduces social costs of inflation because real wage stability is viewed at as being socially desirable. This paper extends the Barro-Gordon model by including costs of real wage fluctuations in the social loss function and endogenizes both, the slope of the Phillips curve and social costs associated with wage indexation. This allows a rigorous comparison of both effects and shows that wage indexation unambiguously reduces the inflation bias but may raise or lower the variance of inflation rates depending on the weight that the central bank attaches to the goal of price stability.

Wage indexation to the price level and wage adjustments to productivity are means to allocate risk stemming from real shocks and monetary policy. From Gray (1976) and Fischer (1977) we know that indexation tends to stabilize output in the case of nominal shocks, but prevents the necessary adjustments to real shocks. In Gray's model, the optimal degree of indexation is an interior solution and corresponds to the relative importance of nominal shocks. This relies on her assumption that wage contracts cannot be conditioned on productivity measures. As Karni (1983) laid out, indexation schemes are capable to duplicate the perfect information equilibrium if wages are indexed to a set of variables that are a sufficient statistic for exogenous shocks. In our model, wage contractors aim at minimizing a weighted average of the variances of employment and real wages. They can achieve an optimal allocation of supply side risk by indexing wages to some measure of productivity. Demand shocks can be neutralized by indexation to prices. Full indexation to the price level makes the real sector immune to monetary policy and eliminates any incentive, to pursue employment goals by inflation. Hence, the central bank concentrates on stabilizing prices and the inflation bias is zero.

In real economies, however, asymmetric information impedes optimal wage adjustments to productivity shocks. Monetary policy can act as a partial substitute for insufficient wage adjustments by responding to temporary supply shocks and smoothing the adjustment process of the real economy to permanent shocks. In the paper, it is shown 
that for suboptimal wage adjustments to productivity, monetary policy improves the allocation of supply side risk at the cost of fluctuating prices. The optimal monetary policy rule balances costs of price fluctuations with efficiency gains from stabilizing the real sector. A high degree of wage indexation hampers real effects of monetary policy on labor markets and raises the variance of inflation rates that is necessary to re-allocate risk in the real sector. Hence, wage indexation may reduce welfare, although it always lowers the inflation bias.

Fischer (1983) argued that wage indexation may raise the variance of the price level, but has no effect on average inflation. Barro and Gordon (1983) have shown that reduced social costs of inflation will have a positive effect on the rate of inflation in a discretionary equilibrium. Fischer and Summers (1989) rely on the same argument and conclude that avoiding inflation mitigation measures is one way of committing to low future inflation rates. Governments whose ability to maintain low rates of inflation is uncertain should not reduce the costs of actual inflation.

On the other side, Giersch (1973) argued that wage indexation helps to avoid reductions in employment during the transition from high to low inflation rates. Crosby (1995) pointed out that indexation disables the government to pursue employment goals and thus, works as a credible commitment to low inflation, but it imposes costs in the form of suboptimal wage adjustments to real shocks. Devereux $(1987,1989)$ incorporates endogenous wage contracts into the Barro-Gordon model and analyzes the relation between average and variance of inflation. Ball (1988) argues that wage indexation is efficient, even in a decentralized economy. But, in his model monetary policy is assumed to be exogenous. Adolph and Wolfstetter (1991) detect informational externalities of wage indexation and show that Ball's result is not robust. If monetary policy depends to indexation, decentralized unions do not account for the positive external effect that indexation has on the inflation bias and the overall degree of indexation may be too low (Waller and VanHoose, 1992). However, this approach does not consider welfare improvements of state contingent monetary policy. If monetary policy responds to supply shocks, indexation creates a negative externality which may reverse the result as we show in this paper.

Ball and Cecchetti (1991) assume a social loss function that depends on real wages only. This accounts for the social costs of inflation that are reduced by wage indexation. Consequently, inflation and welfare increase with the proportion of indexed wage contracts. Duca and VanHoose (2001) assume that wage contracting results from minimizing a weighted average of fluctuations in real wages and employment. They show that greater sectoral output variance reduces the use of nominal wage contracts. Calmfors and Johansson (2002) rely on a similar argument and show that entry in a monetary union implies stronger incentives to use indexed wage contracts.

The next section presents an extended Barro-Gordon model that explicitly considers social costs of wage fluctuations and shows how discretionary monetary policy depends 
on the degree of wage indexation and on wage adjustments with respect to supply shocks. Optimal indexation is analyzed in Section 3. Here, we distinguish between a reference solution with optimal wage flexibility and a second best solution that applies if wage adjustments to productivity are not optimal. Section 4 deals with decentralized economies

in which wage setters choose wage contracts in order to minimize a weighted average of fluctuations in employment and real wages. We show how this choice is influenced by a possible interdiction of wage indexation and proof that a ban on wage indexation to the price level is welfare improving, provided that the inflation bias can be controlled by other means. Section 5 discusses robustness of results with respect to demand shocks. Section 6 concludes this paper.

\section{Discretionary Monetary Policy in the Presence of Wage Indexation}

In the next two sections we describe the interaction between wage setters and a central bank. Wage contracts allow for indexation of nominal wages to the actual price level and for flexible adjustments to supply shocks. The central bank controls the price level in order to minimize a weighted average of fluctuations in employment, prices and real wages around socially desired levels that may deviate from equilibrium levels. The time structure of our model is as follows:

1. Wage setters agree upon a wage contract that specifies the nominal wage as a function of unexpected changes in the aggregate price level and of supply conditions.

2. A supply shock $\theta$ realizes.

3. Monetary authority sets money supply.

4. Firms decide on employment and production. Equilibrium prices are formed simultaneously. Wages are adjusted according to the agreed-upon contract.

The basic variables of our model are nominal wages $w$, price level $p$, employment $l$ and output $y$. Small letters always denote logarithmic terms and may be interpreted as growth rates.

The production function is given by

$$
y=a l+\theta, \quad 0<a<1
$$


where $\theta$ is a random productivity shock, distributed with variance $\sigma_{\theta}^{2}>0$ around a mean of zero. Firms decide on labor demand and output by maximizing their profits. Hence, labor demand is given by

$$
l=\ln \arg \max _{L}\left\{P Y-W L \mid Y=\Theta L^{a}\right\}
$$

where capital letters denote the according non-logarithmic terms. Firms produce a homogeneous good and stand in perfect competition. Maximizing profits yields the labor demand function

$$
l-\bar{l}=\frac{1}{1-a}[p-w+\theta]
$$

where $\bar{l}=\ln a /(1-a)$ is expected employment.

Short run labor supply is assumed to be high enough to meet whatever is demanded, so there is no rationing of firms even in the case of positive shocks. We shall calculate the expected values under this hypothesis. Consistency requires that the support of our random term is limited above, because otherwise short-run labor supply would have to be infinite.

A wage contract is supposed to be a function

$$
w=p^{e}+(1-\lambda)\left(p-p^{e}\right)+\phi \theta .
$$

$p^{e}$ is the expected price level, $1-\lambda$ is the degree of wage indexation to aggregate prices, and $\phi$ is an index for wage adjustments to productivity. From equations (3) and (4) we get the short-run Phillips curve

$$
l-\bar{l}=\frac{1}{1-a}\left[\lambda\left(p-p^{e}\right)+(1-\phi) \theta\right]
$$

A high degree of wage indexation ( $\lambda$ close to 0 ) leads to a steep Phillips curve and a high sacrifice ratio. With a low index of wage adjustments to productivity, the Phillips curve is shifted by supply shocks, i.e. supply shocks have a large impact on employment.

A similar relation obtains for real wages,

$$
w-p=\lambda\left(p^{e}-p\right)+\phi \theta
$$

Equation (6) shows that $\lambda$ is the elasticity of real wages with respect to unexpected inflation. It can be interpreted as the degree to which wages stay behind the price level if 
that exceeds its expected value. $\phi$ is the real wage elasticity w.r.t. productivity. It may be viewed at as the speed of wage adjustments to supply shocks. It may also be interpreted as a productivity bonus. ${ }^{1}$

Aggregate demand is generated by the quantity equation, and prices are assumed to clear the goods market. This defines the price level as

$$
p=m-y,
$$

Using (5), the aggregate production function (1) and quantity equation (7) imply

$$
p-p^{e}=\frac{1}{1+c \lambda}\left[m-\bar{y}-p^{e}-(1+c(1-\phi)) \theta\right]
$$

where $\bar{y}=a \bar{l}$ and $c=a /(1-a)$.

The social loss function is extended by including real wages as an explicit policy goal. It is defined by

$$
C=\left(l-l^{*}\right)^{2}+\beta\left(p-p^{*}\right)^{2}+\gamma\left(w-p-w^{*}\right)^{2},
$$

where $l^{*}, p^{*}$ and $w^{*}$ are desired levels of employment, prices and real wages, $\beta \in[0, \infty]$ is the relative weight on the goal of price stability, and $\gamma \in[0, \infty]$ is the relative weight on the real wage goal. The explicit consideration of real wages in the loss function endogenizes social costs of wage indexation as in Ball and Cecchetti (1991). This term measures the costs that are associated with deviations of real wages from their intended level ${ }^{2}$. Wage indexation reduces real wage fluctuations and associated social costs via this term. Henceforth, costs of price fluctuations, $\beta$, do not depend on wage indexation.

We assume that monetary authorities set money supply $m$ in order to minimize the social loss as defined above.

$$
m=\arg \min _{m} C
$$

Monetary policy determines the inflation bias and how prices depend on supply shocks.

\footnotetext{
${ }^{1}$ Alternatively, one could replace wage adjustments to productivity by adjustments to firm revenues, unemployment or any other variable that depends on productivity, but is not perfectly correlated with prices. Karni (1983) has demonstrated that optimal wage indexation to aggregate prices and output can duplicate the equilibrium that would obtain if wages could be conditioned on the shocks directly. A wage contract that restricts wage adjustments to prices and supply shocks is an analytical simplification.

${ }^{2}$ Ball and Cecchetti (1991) assumed a social loss function that depends on real wages only.
} 
Proposition 1 Discretionary monetary policy in a rational expectations equilibrium is described by the price rule $p=p^{e}-q \theta$ with

$$
p^{e}=p^{*}+\frac{\lambda}{b}\left(c k-g w^{*}\right)
$$

and

$$
q=\lambda \frac{c^{2}-\phi\left(c^{2}+g\right)}{\lambda^{2}\left(c^{2}+g\right)+b}
$$

Proof Solving the central bank's optimization problem (10) with respect to (5), (6) and (8) yields the first order condition $\frac{\partial C}{\partial\left(p-p^{e}\right)} \frac{\partial\left(p-p^{e}\right)}{\partial m}=0$, with $\frac{\partial\left(p-p^{e}\right)}{\partial m}=\frac{1}{1+c \lambda}>0$. Hence, monetary policy is characterized by $\frac{\partial C}{\partial\left(p-p^{e}\right)}=0$, which is equivalent to

$$
\left[\lambda^{2}\left(c^{2}+g\right)+b\right]\left(p-p^{e}\right)+\lambda\left[c^{2}-\phi\left(c^{2}+g\right)\right] \theta=\lambda c k-b\left(p^{e}-p^{*}\right)-\lambda g w^{*},
$$

where $k=a\left(l^{*}-\bar{l}\right), \quad b=a^{2} \beta$, and $g=a^{2} \gamma$. With rational expectations, $p^{e}$ equals the unconditional expectation of $p$ at stage 1 one of the game, $\mathrm{E}(p)$. Applying this to (13) yields the price rule in Proposition 1.

QED

The expected price level $p^{e}$ (or rather the rate of inflation, since we have logarithmic terms) deviates from the socially desired one if and only if $c k \neq g w^{*}$. As we know from standard versions of the Barro-Gordon model, it is higher, the larger the gap $k$ between desired and equilibrium output and the flatter the Phillips curve (larger $c$ ). The real wage goal has an opposite effect. The higher desired real wages $w^{*}$, the lower is inflation. With balanced aspiration levels of employment and real wages, the inflation bias is zero for any degree of wage indexation.

Equation (11) shows that the deviation between expected and desired price level is zero for full indexation $(\lambda=0)$ and rises with falling degree of wage indexation (rising $\lambda)$. A high degree of indexation reduces the capability of monetary policy to influence employment and real wages. It makes the real sector immune to monetary policy. Hence, there is a low incentive to use monetary policy for achieving real effects. The public correctly expects the central bank to concentrate on stabilizing prices and the inflation bias is close to zero in this case.

$q$ is a monetary stabilization term that may have either sign, depending on whether social costs are dominated by employment or real wage fluctuations. (5) and (6) show that wage adjustments to productivity $\phi$ shift uncertainty from employment to real wages. If flexibility is low, employment fluctuations are a more serious threat to welfare than fluctuating wages. In this case the goal of employment stability dominates real wage stability, $q$ is positive, and prices move in opposite direction to aggregate supply shocks. 
A drop in productivity will be accompanied by a rise in prices. This dampens the shock's impact on employment and leads to stronger volatility in real wages. On the other hand, if the central bank thinks that wages overreact to supply shocks, it could reverse the process by creating a positive correlation between productivity and prices.

Monetary policy can substitute wage adjustments to productivity in its task to allocate uncertainty between employment and real wages. However, if monetary policy is used for an active re-allocation of uncertainty between real variables, this leads to undesirable price fluctuations. Proposition 1 implies $\operatorname{Var}(p)=q^{2} \sigma_{\theta}^{2}$. As (12) shows, this variance is smaller, the bigger social costs of price fluctuations $b$ are. If $b$ is very high, or if real effects of prices are low (e.g. for $\lambda$ close to zero), the central bank will hardly use monetary policy to achieve real effects.

It has been suspected that indexation raises the inflationary impact of negative supply shocks ${ }^{3}$. Obviously, this cannot be true in general. In the case of full wage indexation $(\lambda=0)$ real variables are immune to monetary policy, and the central bank will concentrate on stabilizing prices, i.e. $q$ equals zero. Using (12), we find that $\partial q^{2} / \partial \lambda<0$ if and only if $\lambda^{2}>\frac{b}{c^{2}+g}$. This shows that the variance of $p$ rises in the degree of wage indexation $(1-\lambda)$ if and only if $\lambda^{2}>\frac{b}{c^{2}+g}$.

$\frac{b}{c^{2}+g}$ is the relation between social costs of price fluctuations and the costs of real fluctuations. If $b<c^{2}+g$, low degrees of indexation raise price instability until a level is reached where rising marginal costs of price instability outweigh decreasing marginal benefits from stability of real variables. A further increase in indexation is a disincentive for the central bank to use monetary policy to achieve real effects and, therefore, lowers price volatility until its elimination with full indexation. If $b>c^{2}+g$, an increase in wage indexation always lowers the variance of the price level.

\section{Optimal Indexation}

The impact of supply shocks must be borne by real variables. This can best be seen from

$$
(1-a)(l-\bar{l})+(w-p) \equiv \theta
$$

which is implied by Equations (5) and (6). The distribution of a shock's impact on employment and real wages is optimal if it accords with the weights in the social cost function. This distribution can be perfectly controlled by wage adjustments to productivity, summarized by the index $\phi$. If wages adjust in an optimal way, there is no need for monetary

\footnotetext{
${ }^{3}$ Theoretical analysis by Fischer (1983) suggests that indexation raises the inflationary impact of negative supply shocks, his empirical analysis does not support this view.
} 
policy to re-shift fluctuations between real variables. Instead, monetary policy can concentrate on stabilizing prices. Full indexation eliminates the inflation bias, because it works like a credible commitment of the central bank, not to pursue an output or a real wage goal.

Proposition 2 The elasticities of real wages w.r.t. prices and productivity that minimize expected social costs are given by $\lambda^{*}=0$ and $\phi^{*}=\frac{c^{2}}{c^{2}+g}$, leading to $p^{e}=0$ and $q=0$.

\section{Proof see Appendix.}

It accords with basic intuition that optimal wage adjustments to productivity are higher, for a lower relative weight on real wage stability in the social cost function. Setting $g=0$ gives the special case that has been well analyzed by much of the older literature. In this case the optimal degree of wage adjustments is one, preventing any employment fluctuations, as in Karni (1983). But, even for a positive weight on real wage stability, with optinmal wage adjustments to productivity, full indexation minimizes social costs, as in Ball and Cecchetti (1991). ${ }^{4}$

In real economies, however, asymmetric information and moral hazard impede an optimal and immediate adjustment of wages to measures of productivity. In addition, legal and procedural confinements may restrict flexibility of labor markets, as is often claimed especially with respect to European labor markets. Theoretical papers often neglect contingent contracts and implicitly set $\phi=0$, which is an extreme limitation to wage flexibility as it does not allow for any direct wage adjustments to productivity shocks.

If wage adjustments are not optimal, there are two opposing welfare effects: A high degree of indexation lowers the inflation bias and reduces social costs of inflation, but it also disables monetary policy to stabilize real variables in substitution for insufficient wage adjustments, and thus increases social costs of real fluctuations.

If the index of wage adjustments to productivity is stuck below $\phi^{*}$, employment fluctuates too much in comparison to real wages. The central bank can make up for this by letting prices move in opposite direction of shocks, i.e. $q>0$. But, this requires imperfect indexation, since otherwise monetary policy is ineffective. In order to reach a given allocation of uncertainty between real variables, price deviations can be smaller, the lower the degree of indexation is. So, with suboptimal wage adjustments, a low degree of indexation to prices may be advantageous, because it allows to stabilize employment at low costs of price uncertainty.

\footnotetext{
${ }^{4}$ In their model optimal wage adjustments to productivity are zero, because their loss function consists of real wage fluctuations only.
} 
Proposition 3 If the degree of wage adjustments to productivity is not optimal ( $\left.\phi \neq \phi^{*}\right)$ and $c k=g w^{*}$, expected social costs $E(C)$ rise in the degree of wage indexation to prices $(1-\lambda)$.

Proof see Appendix.

If the desired levels of employment and real wages are such that $c k=g w^{*}$, the inflation bias is zero independent of the degree of wage indexation. If, in addition, wage adjustments to productivity are suboptimal, expected social costs unambiguously rise with rising degree of indexation. Reason is the hampering effect of indexation on the effectiveness of monetary policy in its effort to compensate the lack of wage adjustments. Here, the optimal degree of wage indexation is zero.

Following Rogoff (1985) and Walsh (1995) it should be possible to design central bank contracts in such a way that monetary policy aims at minimizing costs of fluctuations without caring for the absolute levels of employment and real wages or to choose a central banker whose preferences fulfill $c k=g w^{*}$. In these cases there is no inflation bias to fear, indexation is irrelevant if wage adjustments to productivity are optimal, and if they are suboptimal we should abstain from wage indexation to prices. This describes a second best solution, and it is remarkable that the second best degree of indexation is zero instead of one in the optimum.

\section{Endogenous Wage Contracts in a Decentralized Economy}

So far, we have compared social costs and benefits of wage indexation for a given degree of wage adjustments to productivity. But, wage contracts are not exogenous. Following Devereux (1987, 1989), Ball (1988), and Waller and VanHoose (1992) we incorporate wage setters' decisions on contract parameters $\lambda$ and $\phi$.

There is a continuum of firms $i \in[0,1]$ with production functions

$$
y_{i}=a l_{i}+\theta_{i}, \quad 0<a<1,
$$

where $\theta_{i}=\theta+\delta_{i} . \quad \delta_{i}$ is the deviation of sector $i$ 's productivity from the aggregate. Without loss of generality we may assume that $\int_{i} \delta_{i} \mathrm{~d} i \equiv 0$. We assume that random terms $\theta$ and $\delta_{i}$ are pairwise independent of each other. The variance of $\delta_{i}$ is denoted by $\sigma_{i}^{2}>0$. Aggregate variables are defined by integrating their sectoral components, e.g. $(w, l, y)=\int_{0}^{1}\left(w_{i}, l_{i}, y_{i}\right) \mathrm{d} i$.

Labor demand in sector $i$ is given by

$$
l_{i}-\bar{l}=\frac{1}{1-a}\left[p-w_{i}+\theta_{i}\right]
$$


A wage contract in sector $i$ is a function

$$
w_{i}=p^{e}+\left(1-\lambda_{i}\right)\left(p-p^{e}\right)+\phi_{i} \theta_{i}
$$

At stage 1 of the game, wage setters specify contract parameters $\lambda_{i}$ and $\phi_{i}$ in order to minimize a weighted average of expected fluctuations in employment and real wages.

$$
\left(\lambda_{i}, \phi_{i}\right)=\arg \min _{\lambda_{i}, \phi_{i}} \operatorname{Var}\left(l_{i}\right)+\zeta \operatorname{Var}\left(w_{i}-p\right)
$$

$\zeta \in[0, \infty]$ represents the relative weight given to the goal of stabilizing real wages ${ }^{5}$.

The solution to this optimization problem depends on price fluctuations which are controlled by the central bank. When deciding on contract parameters, wage setters take the central bank's response to supply shocks into account. Therefore, we distinguish between cases where private contractors' weight on real wage stability $\zeta$ equals, exceeds or falls short of the public weight $\gamma$. For simplicity we assume that $\sigma_{i}$ is the same for all sectors and confine ourselves to symmetric equilibria, where discretionary monetary policy is as described by Proposition (1).

Proposition 4 In an unconstrained symmetric equilibrium, wage adjustments to productivity are given by $\hat{\phi}=1 / z$, with $z=1+\zeta(1-a)^{2}$. If $\zeta \neq \gamma$, wage contractors choose full wage indexation to prices, $\lambda=0$.

\section{Proof see Appendix.}

$\hat{\phi}$ is the unique equilibrium degree of wage adjustments when wage indexation is not constrained. It is an interior optimum for the wage reaction to supply shocks. Higher reactions to supply shocks would hurt desired real wage stability, lower reactions would lead to too strong fluctuations in employment. With direct reactions of wages to supply shocks, the remaining purpose of indexation is to eliminate shocks from unanticipated price movements that may be due to spillover effects from other sectors or from monetary policy. Given monetary policy as specified above, in symmetric equilibria such price movements occur whenever $\phi \neq \phi^{*}$.

Let us first have a look on the special case where $\zeta=\gamma$. This condition says that private and social weight on real wage stability are the same. Here, contracted wage adjustments $\hat{\phi}$ equal $\phi^{*}$. They are regarded as appropriate by the central bank and duplicate the perfect information equilibrium. The distribution of a shock's impact between fluctuations of employment and real wages is optimal and the central bank has no reason to use monetary

\footnotetext{
${ }^{5}$ Cukierman and Lippi (1999) and Lawler (2001) argue that price stability should also be included in the unions objective function. We assume instead that sectors are too small to influence aggregate prices.
} 
policy to redistribute uncertainty. Monetary policy concentrates on stabilizing prices and eliminates all fluctuations here. Hence, indexation serves no purpose and the degree of indexation is irrelevant.

Although monetary policy could achieve the same fluctuations of aggregate employment and real wages as optimal wage adjustments, private contracts achieve this goal better, because they account for sectoral productivity changes while monetary policy can only respond to aggregates. Besides, if monetary policy is used to re-allocate uncertainty between employment and real wages, it also leads to fluctuating prices. This creates a welfare loss that can be avoided if the shock's impact is properly allocated by wage contracts.

If the private weight for real wage stability exceeds the social weight $(\zeta>\gamma)$, then the central bank views wage adjustments to productivity as too low ${ }^{6}$ and is interested in shifting a part of the shock's impact from labor to real wages by creating a negative correlation between supply shocks and price level. For $\zeta<\gamma$ these effects are reversed. ${ }^{7}$ However, such policies can only succeed if $\lambda>0$. Full indexation $(\lambda=0)$ eliminates all possibilities to achieve real effects by monetary policy.

Let us now describe the constrained equilibrium for limited indexation. If indexation is prohibited, the individually optimal degree of wage adjustments to productivity solves (18) with respect to $\lambda=1$. The solution to this problem deviates from the unconstrained optimum, if wage contractors and monetary authority put different weights on the goal of real wage stability.

Lemma 1 If wage contracts cannot be indexed to the price level, in a symmetric equilibrium wage adjustments are given by

$$
\phi=\hat{\phi}\left[1-\frac{a^{2}(\zeta-\gamma)}{b+\left(c^{2}+b+g\right) \sigma_{i}^{2} / \sigma_{\theta}^{2}}\right]
$$

\section{Proof see Appendix.}

If $\zeta>\gamma$, the private weight on real wage stability exceeds the social weight attributed to this goal. Wage setters stipulate suboptimal wage adjustments to productivity and the central bank has an incentive to shift uncertainty from labor to real wages by creating a negative correlation between supply shocks and prices. Wage setters would want to offset the effects of monetary policy by indexing to the price level. But, if wage indexation is restricted, wage negotiators will arrange even lower wage adjustments and, thus, steer against monetary policy. Thus, limits to wage indexation reduce wage adjustments to

\footnotetext{
${ }^{6}$ Suboptimal wage flexibility may also arise, if wage adjustments to productivity are costly, with asymmetric information on productivity measures or when moral hazard is involved.

${ }^{7}$ This case seems less relevant to real economies.
} 
productivity. This might describe the situation in some European and Latin American countries, where wage indexation is forbidden or socially banned. So, we have two opposing effects on welfare: Limiting the degree of indexation makes monetary policy more effective in stabilizing employment and thus, increases welfare. But, the entailed reduction in wage adjustments destabilizes employment and reduces welfare.

If $\zeta<\gamma$, wage negotiators pay too little attention to real wage stability. ${ }^{8}$ If indexation is prohibited, $\phi$ exceeds $\hat{\phi}$. Here, the interdiction of indexed contracts increases wage adjustments to productivity, but again, this is not in the interest of social welfare, because the degree of adjustments exceeds the social optimum already $\left(\hat{\phi}>\phi^{*}\right)$. So, we also have opposing welfare effects of limits to indexation. The next proposition states that the net effect is unique, and for $c k=g w^{*}$ social costs always lower, when indexation to the price level is restricted.

Proposition 5 Assume that $\zeta \neq \gamma$ and $c k=g w^{*}$. If the degree of wage indexation wage indexation can be limited above by $(1-\bar{\lambda})$, expected social costs $E(C)$ rise in $1-\bar{\lambda}$.

\section{Proof see Appendix.}

If $c k=g w^{*}$, the net welfare effect of indexation is unambiguously negative. Hence, a prohibition of indexation $(\bar{\lambda}=1)$ is the second best solution, even with endogenous wage contracting.

Proposition 5 shows that there may be good reasons to interdict wage indexation although it may be desired by wage negotiators. Reason is a conflict in interests between contracting parties (insiders) on one hand and those who are excluded from negotiations (unemployed, outsiders) on the other hand. Without wage indexation, the central bank can correct the distribution of uncertainty that insiders impose on outsiders. The strength of this result comes from the fact that avoiding wage indexation is optimal whenever private and social weights for real wage stability do not coincide. There is no need to argue which one is larger. It is sufficient that two distinct groups of society have different preferences.

Proposition 5 is in sharp contrast to Waller and VanHoose (1992), who emphasized the positive external effect of wage indexation on the inflation bias. Assuming $c k=g w^{*}$, the inflation bias is zero. Our result demonstrates that wage indexation has a negative external effect on stabilizing the economy by state contingent monetary policy.

An interdiction of wage indexation improves welfare if and only if it is possible to keep the inflation bias low by other means, e.g. by appointing a central banker whose aspiration

\footnotetext{
${ }^{8}$ This seems a rather odd assumption, because the social welfare function should also regard the interest of the unemployed who have no advantage from real wage stability. But, note that in some countries social benefits to unemployed or retired people are coupled to wages. So, retired people may be interested in real wage stability while being indifferent to employment figures. Since retired people are an important fraction of all voters, their aims might be over-represented in the government's objective function and spill over to central bank objectives.
} 
levels for employment and real wages are such that $c k-g w^{*}$ is close to zero. If this is not possible, the inflation bias is high without wage indexation, and indexed wage contracts reduce the inflation bias so much that these gains outweigh the losses that are associated with induced stronger volatility in real variables. Thus, indexed wage contracts should be permitted in countries that cannot control the inflation bias otherwise.

Summarizing, we can say that wage indexation lowers welfare if wage reactions to productivity are suboptimal and if the inflation bias can be controlled without indexed wage contracts.

\section{Demand Shocks}

So far, demand shocks were not considered. It is well known from Gray (1976) and Fischer (1977) that indexation is socially desirable if demand shocks are the prevailing sort of uncertainty. In this chapter, we extend the previous model by including monetary shocks that cannot be observed by the central bank ${ }^{9}$. This adds a third condition for a negative welfare effect of wage indexation: wage indexation lowers welfare if wages reactions to productivity are suboptimal, if the inflation bias can be controlled without indexed wage contracts, and if demand shocks are sufficiently small.

Monetary shocks alter the demand equation (7) that is replaced by

$$
p=m-y+v,
$$

where $v$ is a random shock, uncorrelated to productivity shocks $\theta$ and $\delta_{i}$. Since $v$ is not observable by the central bank, price movements are given by

$$
p=p^{e}-q \theta+\frac{1}{1+c \lambda} v
$$

where $p^{e}$ and $q$ are as defined in Proposition 1.

Unconditional expected social loss with demand uncertainty is

$$
\mathrm{E} C=\left.\mathrm{E} C\right|_{v \equiv 0}+\frac{\left(c^{2}+g\right) \lambda^{2}+b}{(1+c \lambda)^{2}} \sigma_{v}^{2}
$$

Optimal wage adjustments to productivity are not altered by introducing demand shocks. Demand shocks make an even more stringent case for wage indexation, as it

\footnotetext{
${ }^{9}$ Any demand shock that is observable by the central bank will be neutralized and has no effect on the real economy.
} 
not only eliminates the inflation bias, but also prevents from demand shocks having real effects.

However, if wages adjust to productivity in a suboptimal way, we have three effects: As laid out above, monetary policy can work as a partial substitute for insufficient wage adjustments if wages are not indexed to the price level. This calls for a low degree of wage indexation. On the other hand, inflation bias and demand shocks are reasons why indexation might improve welfare. The negative welfare effect of indexation is prevailing if aspiration levels of the central bank, regarding employment and real wage goal, are balanced and demand shocks are sufficiently small.

Assuming $\phi \neq \phi^{*}$ and $c k=g w^{*}$, we get

$$
\frac{\partial \mathrm{E} C}{\partial \lambda}=\left.\frac{\partial \mathrm{E} C}{\partial \lambda}\right|_{v \equiv 0}+\frac{2}{a^{2}} \frac{\left(c^{2}+g\right) \lambda+c b}{(1+c \lambda)^{3}} \sigma_{v}^{2}
$$

The first term has been shown to be negative in Propositions 3 and 5 . The second term is positive. If money demand is stable and highly predictable, $\sigma_{v}^{2}$ is small, expected social costs are decreasing in $\lambda$, and non-indexed wage contracts are optimal. Otherwise, $\sigma_{v}^{2}$ is large and indexation has positive welfare effects by insulating the economy from demand shocks that are more important than compensation of insufficient wage adjustments by monetary policy.

\section{Conclusion}

Within the Barro-Gordon model the literature recognized two opposing effects of indexed wage contracts on inflation: a steeper Phillips curve reduces incentives to use inflationary policy, but lower costs of inflation reduce the resistance to inflation. The net effect appeared to be ambiguous. This paper provides a unified framework for studying both effects. Endogenizing social costs of real wage fluctuations, the paper has shown that indexed wage contracts do always reduce the inflation bias.

Welfare effects of indexation are ambiguous, though. While lowering the inflation bias improves welfare, indexed wage contracts reduce the ability of state contingent monetary policy to stabilize the real sector. This reduces welfare. Therefore, policy recommendations must consider the specific situation of a country. If wages respond with sufficient flexibility to changes in productivity, full indexation is socially optimal, because it reduces the inflation bias and insulates the real economy from demand shocks. In this case, there is no need to stabilize the real sector by monetary policy, which voids the negative welfare effect of indexed wage contracts. 
Sufficient wage adjustments to productivity plus full wage indexation are always a first best solution. However, conflicting interests between wage setters and other parts of society and costs of implementing state contingent wage contracts are two important reasons, why wage adjustments to productivity may fall short of the social optimum. If wage adjustments to productivity are suboptimal, while the average rate of inflation can be kept low without indexed wage contracts and money demand is highly predictable, then the negative welfare effects of indexation dominate and wage indexation should be avoided.

Decentralized wage bargaining creates external effects of indexation: A positive effect on the inflation bias had been recognized by Waller and VanHoose (1992) before. In this paper, we have shown that wage indexation generates a negative externality on the ability to stabilize the real economy with monetary policy. Again, policy recommendations are case sensitive: If the inflation bias can be kept at low levels without indexation, a ban on wage indexation improves welfare.

The strongest opposition against the Barro-Gordon model comes from central bankers, who deny that central banks aim at achieving employment above expected levels. If central banks are only concerned with stabilizing prices and real fluctuations, the inflation bias is zero independent of wage indexation. The denial of employment goals has never been convincing, but including real wages in the loss function, as we did in this paper, adds to the plausibility of this argument: The majority of voters is interested in high employment and high wages. Both goals may spill over to monetary policy. But, desires to raise employment and real wages above their expected levels affect the inflation bias in opposing directions and may offset each other.

We can not and did not intend to answer the question whether central banks should care about real variables at all. But, to the extent that monetary policy has implications for employment and real wages, it can be used as a means for macroeconomic stability. With balanced aspiration levels of employment and real wages, there is no inflation bias to fear, and hence, no case against such macroeconomic stabilization within the logic of a Barro-Gordon model. Resulting price fluctuations are weighted against the beneficial stability of other variables. In order to minimize price fluctuations that are associated with an active monetary policy, wage contracts should not be indexed. 


\section{Appendix}

Using (9), (5), (6) and (11), we can express the expected social loss as a function of $\lambda, \phi$ and $q$ :

$$
\begin{gathered}
\mathrm{E} C=\frac{1}{a^{2}}\left[\left(\left(c^{2}+g\right) \lambda^{2}+b\right) q^{2}-2 \lambda\left(c^{2}-\phi\left(c^{2}+g\right)\right) q+\left(c^{2}(1-\phi)^{2}+g \phi^{2}\right)\right] \sigma_{\theta}^{2} \\
+\frac{k^{2}+g\left(w^{*}\right)^{2}}{a^{2}}+\frac{\lambda^{2}}{a^{2} b}\left(c k-g w^{*}\right)^{2} .
\end{gathered}
$$

As $q$ is the optimal stabilization term chosen by the central bank to optimize the welfare function, we have $\partial \mathrm{E} C / \partial q=0$ (envelope theorem). For the other derivatives, we find

$$
\begin{aligned}
& \frac{\partial \mathrm{E} C}{\partial \lambda}=\frac{2 q}{a^{2}}\left[\lambda\left(c^{2}+g\right) q-c^{2}+\phi\left(c^{2}+g\right)\right] \sigma_{\theta}^{2}+\frac{2 \lambda}{a^{2} b}\left(c k-g w^{*}\right)^{2}, \\
& \frac{\partial \mathrm{E} C}{\partial \phi}=\frac{2}{a^{2}}\left[\lambda\left(c^{2}+g\right) q-c^{2}+\phi\left(c^{2}+g\right)\right] \sigma_{\theta}^{2} .
\end{aligned}
$$

Proof of Proposition 2 Using (12), $\partial \mathrm{E} C / \partial \phi=0$ is equivalent to $\phi=\frac{c^{2}}{c^{2}+g}$. Then $q=0$, and $\partial \mathrm{E} C / \partial \lambda=0$ is equivalent to $\lambda=0$.

QED

Proof of Proposition 3 If $c k=g w^{*}$ and the degree of flexibility $\phi \neq \phi^{*}$ is exogenous, expected social loss changes with $\lambda$ according to

$$
\frac{\partial \mathrm{E} C}{\partial \lambda}=\frac{2 q}{a^{2}}\left[\lambda\left(c^{2}+g\right) q-c^{2}+\phi\left(c^{2}+g\right)\right] \sigma_{\theta}^{2}
$$

For $\phi<\phi^{*}\left[\phi>\phi^{*}\right], q$ is positive [negative] and

$$
\begin{aligned}
\frac{\partial \mathrm{E} C}{\partial \lambda}<0 \quad & \Leftrightarrow \quad \lambda\left(c^{2}+g\right) q<[>] c^{2}-\phi\left(c^{2}+g\right) \\
& \Leftrightarrow \quad \lambda^{2}\left(c^{2}+g\right) \frac{c^{2}-\phi\left(c^{2}+g\right)}{\lambda^{2}\left(c^{2}+g\right)+b}<[>] c^{2}-\phi\left(c^{2}+g\right) \\
& \Leftrightarrow \quad 0<[>]\left(c^{2}-\phi\left(c^{2}+g\right)\right) b \quad \Leftrightarrow \quad 0<b .
\end{aligned}
$$


Proof of Proposition 4 In a symmetric equilibrium $\int_{i} \phi_{i} \delta_{i} \mathrm{~d}_{i}=0$. Using (16), (17) and (18), the individually optimal real wage elasticities solve $\min _{\lambda_{i}, \phi_{i}} f\left(\lambda_{i}, \phi_{i}\right)$, where

$$
f\left(\lambda_{i}, \phi_{i}\right)=\lambda_{i}^{2} z \operatorname{Var}(p)+2 \lambda_{i}\left(1-z \phi_{i}\right) \operatorname{Cov}\left(p, \theta_{i}\right)+\left(z \phi_{i}-2\right) \phi_{i} \operatorname{Var}\left(\theta_{i}\right)
$$

and $z=1+\zeta(1-a)^{2}$. The first order conditions are

$$
\begin{aligned}
& \frac{\partial f}{\partial \lambda}=0 \quad \Leftrightarrow \quad \phi_{i}=\frac{1}{z}+\frac{\operatorname{Var}(p)}{\operatorname{Cov}\left(p, \theta_{i}\right)} \lambda_{i}=\frac{1}{z}-q \lambda_{i}, \\
& \frac{\partial f}{\partial \phi}=0 \quad \Leftrightarrow \quad \phi_{i}=\frac{1}{z}+\frac{\operatorname{Cov}\left(p, \theta_{i}\right)}{\operatorname{Var}\left(\theta_{i}\right)} \lambda_{i}=\frac{1}{z}-\frac{\sigma_{\theta}^{2}}{\sigma_{\theta}^{2}+\sigma_{i}^{2}} q \lambda_{i} .
\end{aligned}
$$

As $\sigma_{i}^{2}>0$, they imply $\phi_{i}=1 / z$ for all $i$. Note that $q=0 \Leftrightarrow \phi=\phi^{*}$ and $\phi^{*}=1 / z \Leftrightarrow \gamma=\zeta$. Hence, for $\gamma=\zeta$ the degree of indexation is indetermined. If $\gamma \neq \zeta$, the only solution to the FOC's implies $\lambda_{i}=0$ for all $i$.

QED

Proof of Lemma 1 If $\lambda=1, \phi$ is determined by equation (25). Using (12) and solving for $\phi$ yields equation (19).

QED

Proof of Proposition 5 From (24) we get

$$
\frac{\partial f}{\partial \lambda}=\left[\lambda_{i} z q^{2}-\left(1-z \phi_{i}\right) q\right] 2 \sigma_{\theta}^{2}
$$

If $\zeta \neq \gamma$ and wage indexazion is limited by $(1-\bar{\lambda})<1$, wage contractors will nevertheless choose $\phi_{i}$ according to (25). Using this, $\partial f / \partial \lambda>0$, and wage contractors choose $\lambda_{i}=\bar{\lambda}$. As $\phi$ is determined by (25), we get

$$
\frac{\partial \phi}{\partial \bar{\lambda}}=\frac{-q \sigma_{\theta}^{2}}{\sigma_{\theta}^{2}+\sigma_{i}^{2}} .
$$

Using this the total effect of $\bar{\lambda}$ on welfare is given by

$$
\begin{aligned}
\frac{\mathrm{dE} C}{\mathrm{~d} \lambda} & =\frac{\partial \mathrm{E} C}{\partial \lambda}+\frac{\partial \mathrm{E} C}{\partial \phi} \frac{\partial \phi}{\partial \lambda} \\
& =\frac{2}{a^{2}}\left[\lambda\left(c^{2}+g\right) q-c^{2}+\phi\left(c^{2}+g\right)\right] q \sigma_{i}^{2}=\frac{\partial \mathrm{E} C}{\partial \lambda} \frac{\sigma_{i}^{2}}{\sigma_{\theta}^{2}}<0
\end{aligned}
$$




\section{References}

Adolph, Brigitte, and Elmar Wolfstetter (1991) Wage-Indexation, Information Externalities, and Monetary Policy, Oxford Economic Papers 43, pp. 368-390.

Ball, Laurence (1988) Is Equilibrium Indexation Efficient? Quarterly Journal of Economics 103, pp. 299-311.

Ball, Laurence, and Stephen G. Cecchetti (1991) Wage Indexation and Discretionary Monetary Policy, The American Economic Review 81, pp. 1310-1319.

Barro, Robert J. and David B. Gordon (1983) A Positive Theory of Monetary Policy in a Natural Rate Model, Journal of Political Economy 91, pp. 589-610.

Calmfors, Lars and Åsa Johansson (2002) Nominal Wage Flexibility, Wage Indexation and Monetary Union, Working Paper, Institute for International Economic Studies, Stockholm University.

Crosby, Mark (1995) Wage Indexation and the Time Consistency of Government Policy, Scandinavian Journal of Economics 97, pp. 105-121.

Cukierman, Alex and Francesco Lippi (1999) Central Bank Independence, Centralization of Wage Bargaining, Inflation and Unemployment: Theory and Some Evidence, European Economic Review 43, pp. 1395-1434.

Devereux, Michael (1987) The Effect of Monetary Variability on Welfare in a Simple Macroeconomic Model, Journal of Monetary Economics 19, pp. 427-35.

Devereux, Michael (1989) A Positive Theory of Inflation and Inflation Variance, Economic Inquiry , pp. 105-116.

Duca, John V. and David D. Van Hoose (2001) The Rise of Goods-Market Competition and the Fall of Nominal Wage Contracting: Endogenous Wage Contracting in a Multisector Economy, Journal of Macroeconomics 23, p. 1-29.

Fischer, Stanley (1977) Long-Term Contracts, Rational Expectations, and the Optimal Money Supply Rule, Journal of Political Economy 85, pp. 163-190.

Fischer, Stanley (1983) Indexation and Inflation, Journal of Monetary Economics 12, pp. 519-541.

Fischer, Stanley and Lawrence H. Summers (1989) Should Governments Learn to Live with Inflation? American Economic Review 79, Papers and Proceedings, pp. $382-387$.

Giersch, Herbert (1973) Indexklauseln und Inflationsbekämpfung, Kieler Diskussionsbeiträge 32, Institut für Weltwirtschaft Kiel. 
Gray, Jo Anna (1976) Wage Indexation: A Macroeconomic Approach, Journal of Monetary Economics 2, pp. 221-235.

Karni, Edi (1983) On Optimal Wage Indexation, Journal of Political Economy 91, pp. $282-92$.

Lawler, Phillip (2001) Monetary Policy, Central Bank Objectives, and Social Welfare with Strategic Wage Setting, Oxford Economic Papers 53, pp. 94-113.

Mourmouras, Iannis A. (1993) Time Consistency, Indexation and the Costs of Inflation, Economics Letters 42, pp. 361-365.

Rogoff, Kenneth (1985) The Optimal Degree of Commitment to an Intermediate Monetary Target, Quarterly Journal of Economics 100, pp. 1169-1190.

Waller, Christopher J. and David D. VanHoose (1992) Discretionary Policy and Socially Efficient Wage Indexation, Quarterly Journal of Economics 107, pp. 14511460.

Walsh, Carl E. (1995) Optimal Contracts for Central Bankers, American Economic Review 85, pp. 150-167. 


\section{CESifo Working Paper Series}

(for full list see www.cesifo.de)

801 Saku Aura, Uncommitted Couples: Some Efficiency and Policy Implications of Marital Bargaining, October 2002

802 Wolfram F. Richter, Delaying Integration of Immigrant Labor for the Purpose of Taxation, October 2002

803 Gil S. Epstein and Shmuel Nitzan, The Politics of Randomness, October 2002

804 John Hassler and José V. Rodriguez Mora, Should UI Benefits Really Fall over Time?, October 2002

805 Friedrich Breyer and Stefan Felder, The Dead-anyway Effect Revis(it)ed, October 2002

806 Assar Lindbeck and Solveig Wikström, E-exchange and the Boundary between Households and Organizations, November 2002

807 Dieter Bös, Contests Among Bureaucrats, November 2002

808 Steven Brakman, Harry Garretsen, and Marc Schramm, The Strategic Bombing of German Cities during World War II and its Impact on City Growth, November 2002

809 Florian Englmaier and Achim Wambach, Contracts and Inequity Aversion, November 2002

810 Sarbajit Sengupta, Delegating Recruitment under Asymmetric Information, December 2002

811 Rajshri Jayaraman, On the Partial Public Provision of a Private Good, December 2002

812 Stéphanie Stolz, Banking Supervision in Integrated Financial Markets: Implications for the EU, December 2002

813 Christian Keuschnigg, Taxation of a Venture Capitalist with a Portfolio of Firms, December 2002

814 Inés Macho-Stadler and David Pérez-Castrillo, Settlement in Tax Evasion Prosecution, December 2002

815 Rainer Niemann and Dirk Simons, Costs, Benefits, and Tax-induced Distortions of Stock Option Plans, December 2002

816 Jan-Egbert Sturm and Barry Williams, Deregulation, Entry of Foreign Banks and Bank Efficiency in Australia, December 2002 
817 V. Anton Muscatelli, Patrizio Tirelli, and Carmine Trecroci, Monetary and Fiscal Policy Interactions over the Cycle: Some Empirical Evidence, December 2002

818 Claude Hillinger, A General Theory of Price and Quantity Aggregation and Welfare Measurement, December 2002

819 Erkki Koskela and Ronnie Schöb, Optimal Capital Taxation in Economies with Unionised and Competitive Labour Markets, December 2002

820 Sheilagh Ogilvie, Guilds, Efficiency, and Social Capital: Evidence from German ProtoIndustry, December 2002

821 Hans Gersbach and Verena Liessem, Financing Democracy, December 2002

822 Costas Hadjiyiannis, Panos Hatzipanayotou, and Michael S. Michael, Optimal Tax Policies with Private-Public Clean-Up, Cross-Border Pollution and Capital Mobility, December 2002

823 François Ortalo-Magné and Sven Rady, Homeownership: Low Household Mobility, Volatile Housing Prices, High Income Dispersion, December 2002

824 Syed M. Ahsan and Panagiotis Tsigaris, Measuring the Social Discount Rate under Uncertainty: A Methodology and Application, December 2002

825 Kai A. Konrad, Altruism and Envy in Contests: An Evolutionarily Stable Symbiosis, December 2002

826 Robert S. Chirinko and Huntley Schaller, A Revealed Preference Approach to Understanding Corporate Governance Problems: Evidence from Canada, December 2002

827 Geir B. Asheim, Green National Accounting for Welfare and Sustainability: A Taxonomy of Assumptions and Results, December 2002

828 Andrea Gebauer, Chang Woon Nam, and Rüdiger Parsche, Lessons of the 1999 Abolition of Intra-EU Duty Free Sales for Eastern European EU Candidates, December 2002

829 Giacomo Corneo, Work and Television, December 2002

830 Vivek H. Dehejia and Yiagadeesen Samy, Trade and Labour Standards - Theory, New Empirical Evidence, and Policy Implications, December 2002

831 Geir B. Asheim and Wolfgang Buchholz, A General Approach to Welfare Measurement through National Income Accounting, December 2002

832 Aaron Tornell and Frank Westermann, The Credit Channel in Middle Income Countries, January 2003

833 Gebhard Flaig, Time Series Properties of the German Monthly Production Index, January 2003 
834 Campbell Leith and Jim Malley, Estimated Open Economy New Keynesian Phillips Curves for the G7, January 2003

835 Burkhard Heer and Bernd Süssmuth, Inflation and Wealth Distribution, January 2003

836 Erkki Koskela and Leopold von Thadden, Optimal Factor Taxation under Wage Bargaining - A Dynamic Perspective, January 2003

837 Carola Grün and Stephan Klasen, Growth, Income Distribution, and Well-Being: Comparisons across Space and Time, January 2003

838 Robert S. Chirinko and Ulf von Kalckreuth, On the German Monetary Transmission Mechanism: Interest Rate and Credit Channels for Investment Spending, January 2003

839 Sascha O. Becker, Andrea Ichino, and Giovanni Peri, How Large is the "Brain Drain" from Italy?", January 2003

840 Albert Berry and John Serieux, All About the Giants: Probing the Influences on Growth and Income Inequality at the End of the $20^{\text {th }}$ Century, January 2003

841 Robert Fenge and Martin Werding, Ageing and the Tax Implied in Public Pension Schemes: Simulations for Selected OECD Countries, January 2003

842 Robert Fenge and Martin Werding, Ageing and Fiscal Imbalances Across Generations: Concepts of Measurement, January 2003

843 Giovanni Andrea Cornia, The Impact of Liberalisation and Globalisation on Income Inequality in Developing and Transitional Economies, January 2003

844 Peter Fredriksson and Per Johansson, Program Evaluation and Random Program Starts, January 2003

845 Bernd Hayo and Matthias Wrede, Fiscal Equalisation: Principles and an Application to the European Union, January 2003

846 Syed M. Ahsan and Jaideep Oberoi, Inequality, Well-being and Institutions in Latin America and the Caribbean, January 2003

847 Chang Woon Nam and Doina Maria Radulescu, The Role of Tax Depreciation for Investment Decisions: A Comparison of European Transition Countries, January 2003

848 V. Bhaskar and Steinar Holden, Wage Differentiation via Subsidised General Training, January 2003

849 Paloma Lopez-Garcia, Labour Market Performance and Start-up Costs: OECD Evidence, January 2003

850 Christian Keuschnigg and Soren Bo Nielsen, Public Policy for Start-up Entrepreneurship with Venture Capital and Bank Finance, January 2003 
851 Yin-Wong Cheung, Menzie D. Chinn, and Eiji Fujii, China, Hong Kong, and Taiwan: A Quantitative Assessment of Real and Financial Integration, January 2003

852 Gregory D. Hess, The Economic Welfare Cost of Conflict: An Empirical Assessment, February 2003

853 Douglas J. Cumming and Jeffrey G. MacIntosh, Comparative Venture Capital Governance. Private versus Labour Sponsored Venture Capital Funds, February 2003

854 Eckhard Janeba and John Douglas Wilson, Decentralization and International Tax Competition, February 2003

855 Tapio Palokangas, Capital Accumulation and Employment Cycles in a Model of Creative Destruction, February 2003

856 Brendan Walsh, When Unemployment Disappears: Ireland in the 1990s, February 2003

857 Luis H. R. Alvarez and Erkki Koskela, A General Approach to the Stochastic Rotation Problem with Amenity Valuation, February 2003

858 Christian Schultz, Strategic Campaigns and Redistributive Politics, February 2003

859 Ernst Fehr and Joseph Henrich, Is Strong Reciprocity a Maladaptation? On the Evolutionary Foundations of Human Altruism, February 2003

860 Haizhou Huang, Dalia Marin, and Chenggang Xu, Financial Crisis, Economic Recovery and Banking Development in Former Soviet Union Economies, February 2003

861 Pedro Cardoso and Bernard M.S. van Praag, How Sustainable Are Old-age Pensions in a Shrinking Population with Endogenous Labour Supply?, February 2003

862 Volker Meier, Efficient Transfer of Aging Provisions in Private Health Insurance, February 2003

863 Edward Castronova, Theory of the Avatar, February 2003

864 Robert S. Chirinko, Hans van Ees, Harry Garretsen, and Elmer Sterken, Investor Protections and Concentrated Ownership: Assessing Corporate Control Mechanisms in the Netherlands, February 2003

865 Bernard M.S. van Praag and Pedro Cardoso, The Mix Between Pay-as-you-go and Funded Pensions and what Demography has to do with it, February 2003

866 Ernst Fehr, Urs Fischbacher, Bernhard von Rosenbladt, Jürgen Schupp, and Gert G. Wagner, A Nation-Wide Laboratory. Examining Trust and Trustworthiness by Integrating Behavioral Experiments into Representative Survey, February 2003

867 Frank Heinemann, The Inflationary Impact of Wage Indexation, February 2003 